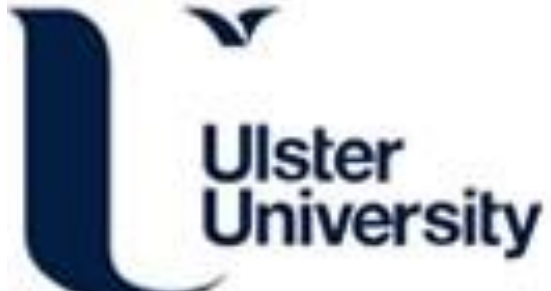

\section{Face-to-face contact in blended learning for intercultural education: the role of teachers}

Austin, R., Rickard, A., \& Reilly, J. (2017). Face-to-face contact in blended learning for intercultural education: the role of teachers. Irish Educational Studies, 2017, n/a, 323-340.

https://doi.org/10.1080/03323315.2017.1327364

Link to publication record in Ulster University Research Portal

\section{Published in:}

Irish Educational Studies, 2017

Publication Status:

Published (in print/issue): 05/06/2017

DOI:

10.1080/03323315.2017.1327364

\section{Document Version}

Author Accepted version

\section{General rights}

Copyright for the publications made accessible via Ulster University's Research Portal is retained by the author(s) and / or other copyright owners and it is a condition of accessing these publications that users recognise and abide by the legal requirements associated with these rights.

\section{Take down policy}

The Research Portal is Ulster University's institutional repository that provides access to Ulster's research outputs. Every effort has been made to ensure that content in the Research Portal does not infringe any person's rights, or applicable UK laws. If you discover content in the Research Portal that you believe breaches copyright or violates any law, please contact pure-support@ulster.ac.uk. 


\section{Face-to-face contact in blended learning for intercultural education: the role of teachers}

\section{Roger Austin, Angela Rickard \& Jacqueline Reilly}

To cite this article: Roger Austin, Angela Rickard \& Jacqueline Reilly (2017): Face-to-face contact in blended learning for intercultural education: the role of teachers, Irish Educational Studies, DOI: 10.1080/03323315.2017.1327364

To link to this article: http://dx.doi.org/10.1080/03323315.2017.1327364

册 Published online: 05 Jun 2017.

Submit your article to this journal $\pi$

View related articles

View Crossmark data \lceil 


\title{
Face-to-face contact in blended learning for intercultural education: the role of teachers
}

\author{
Roger Austin ${ }^{\mathrm{a} *}$, Angela Rickard ${ }^{\mathrm{b}}$ and Jacqueline Reilly \\ ${ }^{a}$ School of Education, Ulster University, Coleraine, Northern Ireland, UK; ${ }^{b}$ Department of \\ Education, Maynooth University, Maynooth, Ireland
}

(Received 19 September 2016; accepted 29 April 2017)

In societies experiencing or emerging from conflict, teachers often deliver educational programmes designed to build community cohesion. We report on research which examined teachers' views of the implementation of a programme involving both face-to-face and online contact between pupils. Findings suggest that this blended approach is highly motivational, enhancing online work and relationship building. The research underlines the importance of the political, educational and historical context for work of this sort and the impact this has on the particular blend of online and face-to-face interaction. Implications for policymakers and teachers include value for money and sustainability of blended intercultural education in similar contexts.

Keywords: intercultural education; blended contact between pupils; peace-building in Ireland

\section{Introduction}

For decades, research on the role of contact between different ethnic or religious groups has drawn on contact theory, first formulated as the contact hypothesis by Gordon Allport in his work entitled The Nature of Prejudice (1954). Allport's work has been used as a theoretical framework to examine the conditions in which contact between different social groups is most likely to lead to positive attitudinal changes and improved social harmony. Despite its popularity in social science research (see Pettigrew and Tropp 2008) Allport's contact hypothesis has been subject to critique largely for its 'unspoken assumption' that prejudice, 'conceived as residing in individual personality', was 'the source of intergroup strife' (Zuma 2014, 44) and for the theory's neglect of wider societal and structural impediments to parity of esteem across divided social groups (Connolly 2000; Dixon, Durrheim, and Tredoux 2005). Pettigrew and Tropp (2008) argue that while intergroup contact is not a panacea for intergroup conflict, contact is an essential, if insufficient, component for lasting remedies. Research studies have shown that this is indeed the case, not only for face-to-face contact (Hughes 2014) but also for online contact (Austin et al. 2010; Austin and Hunter 2013).

While the contact hypothesis has been an essential element in framing our own research, more recent studies such as that of Çiftçi (2016) have summarised previous

\footnotetext{
*Corresponding author. Email: rsp.austin@ulster.ac.uk 
research on the role of computer-based digital technologies in intercultural learning. Although the focus for this summary was primarily the online elements used by undergraduate students in foreign languages to develop intercultural communicative competence (ICC), some of the findings from this review are also relevant to our work.

Similarly, we have drawn upon research findings in blended learning and in particular on the role of the research context (Dziuban et al. 2016) to shape our interpretation of the effectiveness of online learning and face-to-face contact.

In this article, we report on our work with teachers on a cross-border, school-based exchange project, entitled Dissolving Boundaries (DB), to examine the relationship between face-to-face contact and online interaction. We highlight the importance of the context in which this work took place, namely, the relatively young age of the participants, around 10-12 years of age, the socio-political situation on the island of Ireland and the demographic characteristics the population. All of these affected the ways that online tools and face-to-face encounters were managed.

We start by outlining the political context for the DB programme, initiated in 1999 and funded until 2014. We explain how this programme was implemented, before examining previous research on both face-to-face contact and online contact within intercultural education programmes internationally. We then highlight our research questions, describe the research methodology and findings before concluding with a discussion of their implications for policymakers and teachers including the value for money and sustainability aspects of blended intercultural education in similar contexts.

\subsection{Research context}

\subsubsection{Political background}

While much of the focus of research on dealing with the legacy of conflict on the island of Ireland has concentrated on Northern Ireland (NI) (see, for example, Gallagher 2008; Bekerman, Zembylas, and McGlynn 2009), one of the central strands of the 1998 Belfast/Good Friday Agreement that brought a partial end to the armed conflict, was concerned with relations between NI and, across the border, the rest of the island of Ireland (previously referred to as the Republic of Ireland and since 1999, simply Ireland) This was seen to be pivotal since it was believed that the Irish claim to seek a united Ireland, enshrined in the Irish constitution as articles 2 and 3, gave legitimacy to the armed campaign of the Irish Republican Army. In 1999, a referendum in Ireland led to a repeal of articles 2 and 3 of the constitution and this paved the way for an understanding that a united Ireland would only come about if a majority of those living in NI decided that this was what they wanted. This was a particularly important consideration for Protestants in NI who have traditionally shown allegiance to the United Kingdom rather than to Ireland. It remains the case that the largest party in NI which has the support of the majority of the Protestant population, the Democratic Unionist Party, still regard cross-border contact with caution. In turn, this means that schools in NI which have a mainly Protestant enrolment have to tread warily in any educational cross-border work. Data from this study show that schools of this type were less likely to participate than ones which had a Catholic enrolment.

As a result of the agreement, a wider process of normalising cross-border relations was put in place between NI and Ireland, given that the conflict had negatively impacted on the development of political, economic and social relationships on the 
island of Ireland. As part of this process of seeking to normalise cross-border relations, educational initiatives were introduced which included the DB programme under discussion in this article. In the year when data was collected for this research, 2013-2014, political conditions both within NI and on the island of Ireland were relatively normal. However, it is important to note that in spite of the relative absence of violence and a gradual process of cross-border normalisation through sport and business, it was still unusual for children on either side of the border to be using technology for intercultural learning on an all-Ireland basis as a regular part of their school lives.

\subsubsection{Educational response: the DB programme}

The DB programme was funded by both the Department of Education in NI and the Department of Education and Skills in Ireland to use technology and face-to-face contact to help young people work together. Since its inception, DB expanded steadily and between 1999 and 2014 involved some 50,000 young people aged 8-18 years from a range of different types of special, primary and post-primary schools. Schools volunteered to take part and were partnered together, with one on each side of the border and, as far as possible, with children of roughly the same age. On average, 100 schools took part each year on each side of the border.

The importance of careful planning in work of this sort has been underlined in Çiftçi's (2016) review of previous research. He notes the work of both Furcsa (2009) and Hauck (2007) as lending weight to the need for careful design of interesting activities. On the DB programme, teachers were invited to a conference each September where they planned the work they would do with their respective classes on agreed aspects of the curriculum and how they would use a combination of a Virtual Learning Environment (VLE) (Moodle), video-conferencing and a face-to-face meeting to engage their pupils in collaborative learning. It is worth underlining the importance of these three inter-connected elements since the first of them is entirely absent from Çiftçi's review of previous research. His review (315) highlights online message boards, text-based chat and blogs as the tools used most frequently in the projects that were reviewed. In the design of the DB programme, however, the VLE was an essential element in allowing teachers and children to have an online space in which to carry out joint curricular work. The VLE provided a forum for the exchange of social information, a place to clarify ongoing work while the 'wiki' in the VLE created a space for pupils to share the knowledge they had learned on their topics. We emphasise this point here to take account of the views of Perry and Southwell (2011) on the need for researchers to show clearly how different features of online contact and face-to-face work have enhanced intercultural competence.

Drawing on contact hypothesis research, teachers were advised that links should be group to group and with children of roughly the same learning ability. Teachers created a plan of their proposed work, basing all activities within the respective curricula in their schools. Copies of the plan were shared with the school principal/Board to consolidate the institutional support for it (Pettigrew 1998). In most cases, the plans were based on contact being made online initially with an exchange of personal data, followed by a mixture of video-conference contact, joint work around a topic in the curriculum and a face-to-face meeting. It should be noted that unlike conventional blended learning courses, where it is assumed that the primary goal of such learning is to extend academic knowledge (Dziuban et al. 2016), the purpose of the DB 
cross-border school link had an explicit social and civic dimension. The programme team made it clear to teachers that while their work should be based on the respective curricula in both jurisdictions, the goal was to create opportunities for children to work together collaboratively in order to understand each other as well as to acquire knowledge of the topic under study.

It should be underlined that it was not a requirement of participation in the programme that teachers organise a face-to-face meeting but they were encouraged to do so wherever possible. Given the age of the youngest participants in the programme, around 8 years, the physical distance between schools, on average 200 miles (320 kilometres), and the prohibitive costs of overnight accommodation, most face-to-face meetings took place in a single day and involved the 2 schools travelling to an agreed mid-way location such as an outdoor pursuit centre or cultural venue. It is important to stress the nature of the face-to-face contact which took place; it was of relatively short duration and its purpose was often more about intercultural education than academic study. In these two critical respects, the model of 'blended contact' in DB was very different from the cases described in current research on blended learning such as those described by Dziuban et al. (2016) which overwhelmingly refer to courses in higher education where university students have a mix of face-to-face and online course delivery.

Two further contextual points are relevant; first, $50 \%$ of the schools that took part in DB in NI were categorised as having either educational or socio-economic disadvantage. Second, it should also be noted that on the NI side of the programme $35 \%$ of the schools that chose to take part were mainly Protestant in their intake and these are referred to as 'controlled' schools; this is important since, as we noted above, this section of the population would normally value their ties with the rest of the United Kingdom rather than Ireland. The reluctance of mainly Protestant schools to participate in cross-border work can also be gauged by the fact that in the total school population, Protestant schools make up close to $50 \%$ of the total number of schools in NI. In other words, Protestant schools were slightly under-represented in the DB programme whereas Catholic schools in NI, referred to as 'maintained' schools, were slightly over-represented, consistent with longstanding observations that Protestants demonstrate less enthusiasm for inter-religious mixing (e.g. Hughes and Donnelly 2001). Schools that educate both Catholic and Protestant children together make up $7 \%$ of the total school population and are referred to as 'integrated' schools.

\subsection{Current research on the role of contact and blended learning in intercultural education}

The complexity of intergroup contact is addressed by many researchers, including Tropp and Pettigrew (2005) who refer to the ways that contact can reduce affective (emotional) and cognitive (intellectual) prejudice. In a later paper, the same authors contend that intergroup contact is an essential factor in resolving intergroup conflict, albeit not the only necessary factor (Pettigrew and Tropp 2008). Much of the research done on the role of contact between young people in programmes designed to build intercultural links, whether within NI, on the island of Ireland, England or in Israel, has looked at the ways that the contact hypothesis might be used to help programme designers refine the work they do (Kilpatrick and Leitch 2004; Bekerman and 
Nir 2006; Atkinson et al. 2007; Hughes 2007; Yablon 2007; Binder et al. 2009; King 2009; Hughes and Blaylock 2013). For example, most researchers underline the importance of contact being long-term rather than short-term, being cooperative rather than competitive, based on group to group rather than one to one and having institutional support to validate the work of individual teachers. In spite of some criticisms of the theory and its application in practice, that it is underpinned by an over emphasis on individualism (Dixon, Durrheim, and Tredoux 2005; Zuma 2010, 2014) or that it does little to alter the wider social structures that protect a dominant group, (Jackman and Crane 1986; Connolly 2000; Dixon et al. 2012; Barlow et al. 2013) it has continued to be highly influential. As Dixon, Durrheim, and Tredoux (2005) note:

we are not rejecting the contact hypothesis in principle or suggesting that its recommendations are without merit. To the contrary, like the majority of contact researchers, we believe that de-segregation often has the potential to transform society for the better. Left to develop in isolation one's assumptions about others tend to become inflexible and self-referential. (707)

Austin and Hunter (2013) underline the emerging consensus that it is not contact per se that lies at the heart of this work but the nature of the contact (Tropp and Pettigrew 2005; Hughes 2007; Ligorio and van der Meijden 2008; Hughes 2014). Rickard et al. (2014) argue that it is incumbent on teachers to be aware of and proactive in ways to develop among their pupils positive attitudes about others.

In a review of the research, however, Rickard et al. (2014) noted two issues on which there appeared to have been relatively little work done. The first was the relationship between face-to-face contact and online interaction. Merryfield (2001) suggested that teacher education programmes consider how face-to-face cross-cultural experiential interaction and online interaction could complement each other. In a comprehensive summary of research on intergroup contact, Harwood et al. (2013) refer to the ways that online contact can overcome three of the challenges of faceto-face contact, namely practicality, anxiety and generalisation. Practicality refers to the practical problems to do with organising face-to-face meetings, the second refers to the evidence that initial contact between groups online is less stressful than face-to-face encounters since the participants have more control over how they present themselves and the third refers to the findings that while many face-to-face contacts work well at the interpersonal level, positive feelings may not necessarily be transferred to the 'out-group' as a whole. They contend that current work needs to examine further the respective contributions that face-to-face and online work can make to the field.

For our research we were particularly interested to examine teacher perceptions of the relative importance of the online and face-to-face elements of the pupil interaction given that, as we noted above, while online work is necessary, it is not necessarily sufficient.

The second area that seemed relatively under-researched was evaluation of face-toface meetings both as 'stand-alone' features of contact programmes and as part of blended programmes that used a combination of face-to-face and online work. Data on the effect of face-to-face programmes has produced mixed results. For example, Trew (1989) and O'Connor, Hartop, and McCully (2002) were relatively negative about face-to-face contact schemes but more recently Abrams (2010) has argued 
that both intergroup contact and school diversity tend to be associated with better intergroup understanding and more positive attitudes. This was of considerable interest to us because on average, since the start of the programme in 1999, around $65 \%$ of teachers in the DB programme have organised a face-to-face meeting as part of their planned activities.

We noted that while there has been considerable recent research into the use of online and blended learning with older school-aged pupils and for those with special needs (Barbour, Brown, and Waters 2011; Barshay 2011; Schorr and McGriff 2012; Kassner 2013; Lotrechianno et al. 2013; Borup et al. 2014; Kuo et al. 2014; Westermann 2014; Morgan 2015), none of this work was concerned with learning that had a clear intercultural dimension. Similarly, the recent study by Dziuban et al. (2016) on research in online and blended learning environments highlighted the paucity of research on the role of blended learning with school-age pupils. This lacuna is also underlined by Çiftçi (2016) who concluded that 'interactions between different profiles other than undergraduate students may also provide future research with fresh perspectives' (322). His review also noted that the majority of studies on the use of online work to develop ICC were generally for one semester (322). In DB, however, insights from the contact hypothesis theory had led the programme team to the view that since successful contact was more likely to occur through long-term rather than short-term contact, teachers should plan work for a whole school year.

Finally, we noted the work of Perry and Southwell (2011) who commented that

The degree to which intercultural competence can be developed via digital technologies has not yet been examined thoroughly. Most of the current research is limited to exploring the pedagogical dimensions and potential of digital technologies for developing intercultural competences rather than its effectiveness per se. (458)

\subsection{Research focus}

Our analysis of previous research led us to focus our enquiry on one broad area. While a number of studies have reported on the impact of the DB programme on young people (Bonnell et al. 2011; ETI/DES 2012; Rickard et al. 2014), and on other elements of the work, such as teachers' perceptions of collaborative crossborder work (Austin et al. 2010), teachers' views of how the face-to-face visit linked into online contact merited investigation. Therefore, as part of an evaluation of the project, we sought to learn about the following: whether the timing of the face-to-face meetings was an important variable; the types of location selected by teachers and the rationale for the choice; the types of activities carried out online both before and after the face-to-face contact; the types of activities undertaken at the face-to-face meetings; and the effect teachers thought these had on both the children and the teachers. In other words, developing Perry and Southwell's suggestion (2011), we wanted to examine the interplay of digital technologies with faceto-face contact.

\section{Methods and sample characteristics}

A sequential exploratory mixed method approach was adopted (Creswell 2003). In the first instance, interviews with teachers were conducted and analysed, with the findings 
from these employed in the design of a questionnaire for wider distribution to all the teachers on the programme in a second phase of data collection. Teachers' views were elicited through in-depth interviews in a cross-section of schools; this yielded 17 responses from special, primary and post-primary teachers. This sample was purposefully selected to provide a spectrum of experience, school characteristics and school types. In NI, teachers from 8 primary schools ( 2 controlled, 4 maintained, 1 integrated and 1 special school ${ }^{1}$ ) and 2 post-primary schools ( 1 controlled and 1 maintained) participated. In Ireland, teachers from six primary schools participated and one was from a special school. These interviews, lasting around 45 minutes each and mainly conducted in the teachers' schools, focused on teacher experiences of involvement in face-to-face meetings, and were conducted by the DB team. The data were then transcribed and thematically analysed by one member of the research team, broadly following Braun and Clarke (2006) in a process of coding, generation of themes, and review. Initial themes were then discussed with the other colleagues until consensus was reached. Findings were then used to inform the design of an online questionnaire for a larger sample of teachers.

The draft version of the questionnaire was piloted with three teachers who were not connected to the project, very minor refinements were made and the survey was then sent to all DB teachers in May 2014. Responses totalled 146, representing 75\% of all DB participating teachers. Of these, $84 \%$ were from primary schools, $9 \%$ from postprimary and $7 \%$ from special schools. Forty-five per cent of responses were from teachers in NI and 55\% from teachers in Ireland. Forty-two per cent of respondents had been teaching for more than 11 years, $58 \%$ for less than that. Eighty per cent of teachers had been involved in the programme for $1-3$ years, $19 \%$ for longer than that. Seventy-five per cent had been involved in between one and three face-to-face meetings and $16 \%$ in more than that. The volume of responses, the depth of experience of the teachers and the range of schools from within each jurisdiction and on both sides of the border, support the validity and reliability of findings. In the following sections data from both teacher interviews and the survey are used to address the research questions.

\subsection{Proportion of schools that had face-to-face meetings}

Given that face-to-face meetings were optional, it was important to establish what proportion of schools had chosen to carry out this aspect of the programme. We wanted to get a clear understanding of the relative importance attached by teachers to this compared to the required video-conferencing and online interaction parts of the link. In 2013-2014, the year in which teachers were asked for their views, project records indicate that $75 \%$ of partnerships had a face-to-face meeting (for the previous three years an average of $65 \%$ of participating schools had done so). However, $92 \%$ of the questionnaire respondents had participated in a face-to-face meeting indicating that unsurprisingly, those who had done so were over-represented in the sample. Of the respondents to the questionnaire who indicated that they had not held a face-toface meeting $(8 \%)$, reasons given were to do with the costs involved, health problems of staff, pressures in school due to inspections and the difficulties, especially in postprimary schools, of finding time to take children out of school. These figures suggest that face-to-face meetings were considered a valuable part of participation in the project. 


\section{Findings}

In order to explore the kinds of face-to-face meetings that seemed most effective in developing intercultural learning as an element of a longer online intercultural contact scheme, we looked at the timing of meetings, their purpose, location and cost as well as satisfaction with meetings. Our data also threw light on the connection between the face-to-face elements of contact and the online engagement of pupils.

\subsection{Timing of face-to-face meetings}

Teachers were advised at the planning conference of the benefits of holding face-toface meetings early in the school year, to strengthen the partnership and allow time for pupils to continue interacting online after they have met; we were therefore interested to find out both teachers' views on the ideal time for a face-to-face meeting and when these meetings were actually held, illustrated in Figure 1.

Figure 1 illustrates that most teachers believed mid-year or late in the school year were ideal times for a face-to-face meeting, as one teacher explained:

we think February is the best because they've done a little bit of delving around to find out something about the kids between September and Christmas, and then the face-to-face means they can put a face to who is on the other end and they've met them and played ten pin bowling with them, ... it makes the web conferencing better because they're looking for their friends. (NI post-primary school) ${ }^{2}$

This response, fairly typical of most of the comments, shows that although political conditions were fairly stable with little risk to children of travelling across the

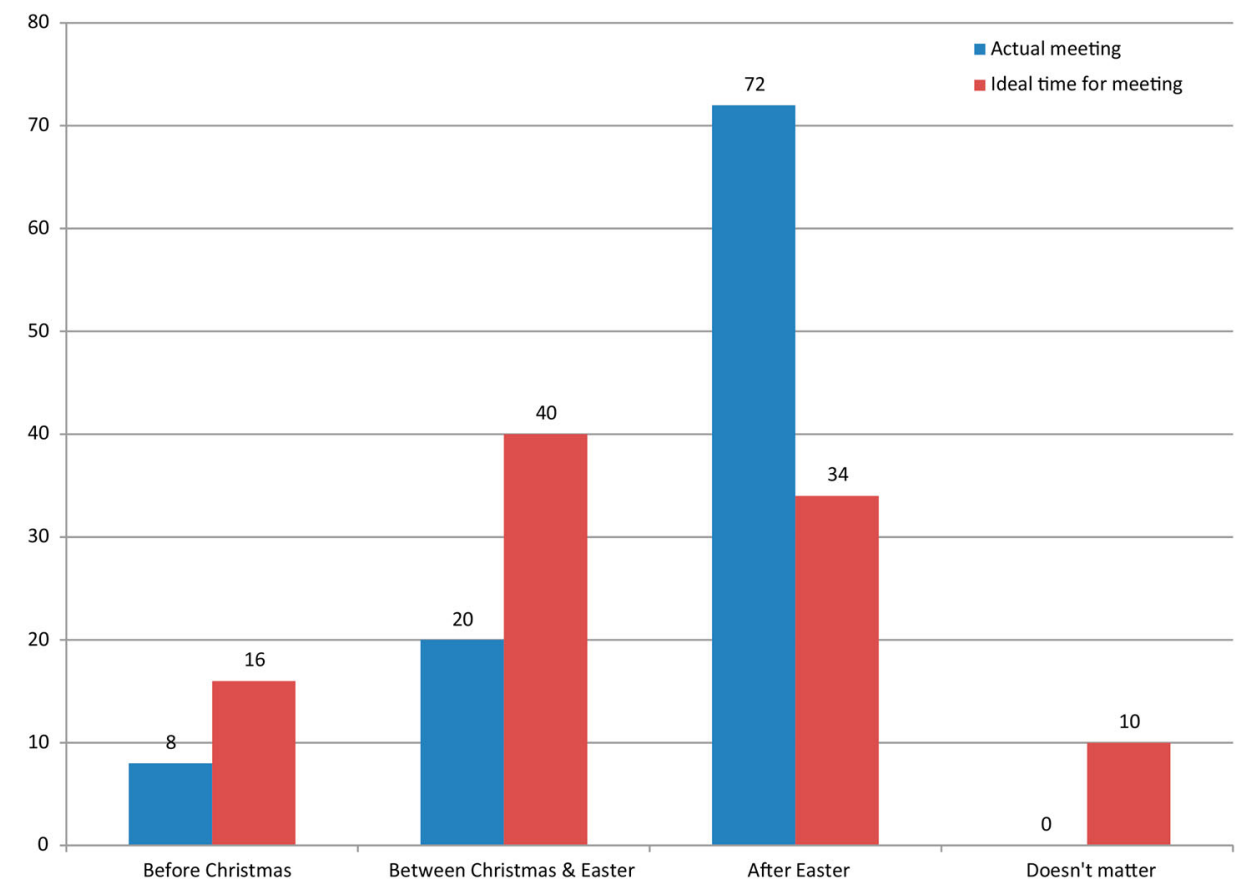

Figure 1. Ideal and actual times of face-to-face meetings. 
border, teachers still felt that it was preferable to use online contact, whether through text or video-conferencing for a substantial period of time. In part, this is likely to reflect teachers' need to reassure parents that their children would not be at any risk; in some cases, particularly in some predominantly Protestant schools in NI, there would have been an additional concern to allay any anxieties that the programme was encouraging children to support the idea of a 'united' Ireland. (It is still the case that supporters of Unionist parties in NI cherish their links with the rest of the United Kingdom and are, at times, concerned about losing their identity should NI be 'united' with what they would refer to as 'the south of Ireland'.)

However, it is also evident from Figure 1 that the ideal time and the actual timing of the meetings differed. The data indicate that only $8 \%$ held their meeting before Christmas, 20\% between Christmas and Easter and 72\% after Easter. These results suggest possible difficulties in arranging meetings, possibly related to the point above. In addition, $10 \%$ of respondents did not think it mattered when face-to-face meetings were held, and 16\% reported that early in the school year provided a good start to the programme as one teacher noted:

\begin{abstract}
Yes, we had ours very early on, I think it was the end of September, beginning of October time, we had our face-to-face meeting and we went down to an outdoor pursuit centre in Tanagh. I think it is a good idea to have it initially so that the friendships can be established right away, it was good for me to meet the teacher, for us to have a good working relationship and it was great for the children to see [each other]. (NI primary school)
\end{abstract}

The fact that $72 \%$ of the teachers chose to do a face-to-face meeting relatively late is interesting, suggesting that most teachers were content to start the project with online interaction.

\title{
3.2. Purpose and location
}

We wanted to find out more about what teachers saw as the main reason for holding a face-to-face and their views about the best location. In the past, schools have met in outdoor/indoor pursuits centres, each other's schools or an educational venue such as a zoo, planetarium or historical site connected to the work they had been doing for their joint curricular project in school.

As Figure 2 illustrates, $59 \%$ of teachers in the survey said the main purpose of having a face-to-face was to give pupils the opportunity to socialise and get to know each other; one of the responses that was typical of those who replied in this way was from a teacher who wrote:

the most important element of the Dissolving Boundaries project is to let the children get to know one another without prejudices. That is why I think it is important for them to socialise with one another. It means they 'know' who they are communicating with. (Questionnaire response)

This coincides with Davies' examination of the role of face-to-face contact in the development of children's affinities (Davies 2012). Other reasons given for having a face-toface meeting were 'to consolidate learning on curriculum related work' (14\%), 'something to look forward to during the school year' (14\%) and to 'kick-start the project and stimulate later online interaction' $(13 \%)$. 


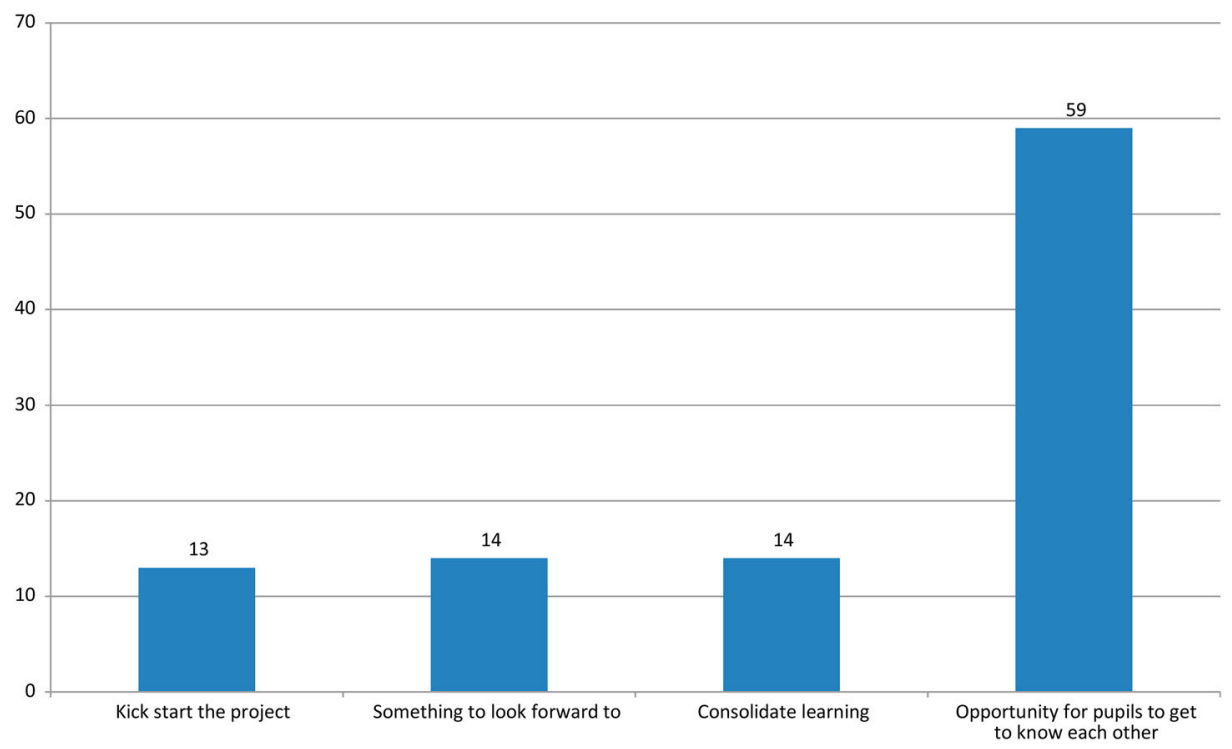

Figure 2. Main purpose of face-to-face meeting.

It is perhaps no surprise then to find that in response to a question about the ideal location (see Figure 3), most respondents (57\%) said that an 'outdoor/indoor centre' was their first choice since it offered specialist instructors who were, as one teacher said, 'skilled in team building and cooperative learning' (questionnaire response). Also popular were educational venues such as a zoo or museum $(24 \%)$ while only $13 \%$ opted for a visit to the partner school and $6 \%$ preferred the inexpensive choice

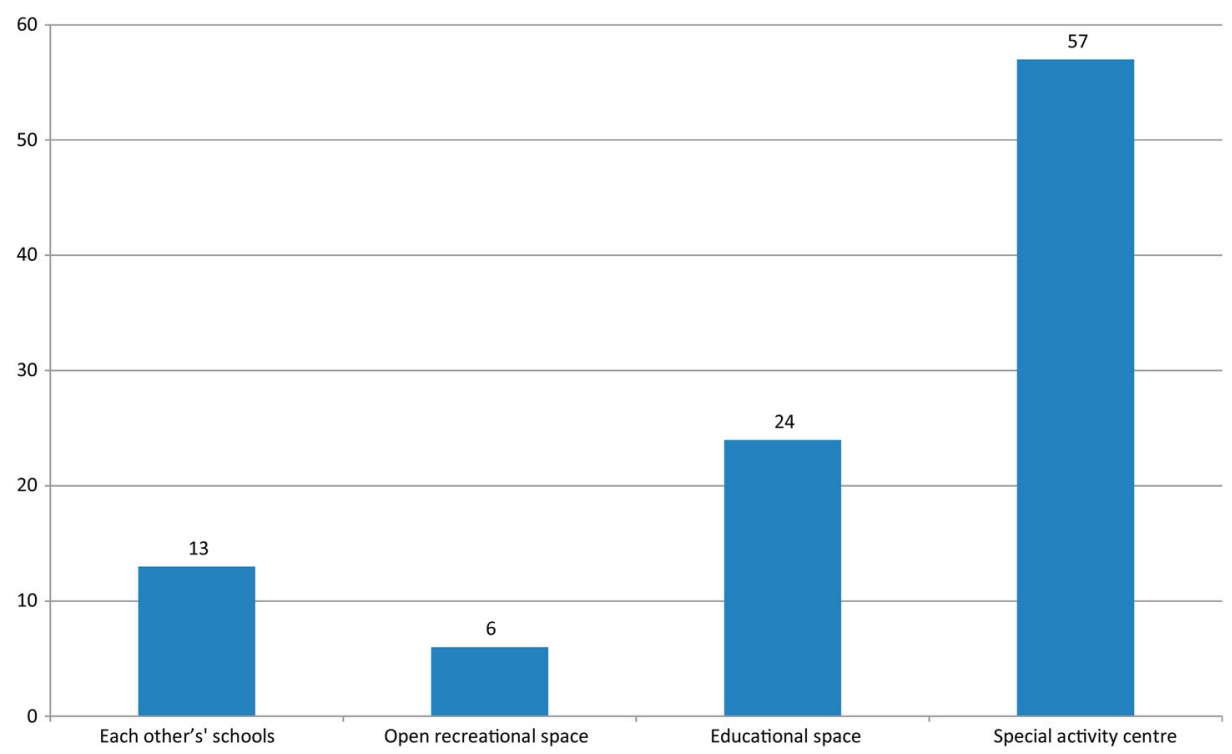

Figure 3. Ideal venue type for face-to-face meeting. 
of a park or freely accessible sports field. The low figure for a visit to the partner school, just $13 \%$ of the total, probably reflects two things. The first is the practicalities of further travel than might be the case if a venue half way between the schools had been chosen but the second is the possibility that a school visit moves the participants from a 'neutral venue' to one that requires one side to be inside the 'territory' of the other. We know from other research the issue of 'place' or 'territory' is bound up with definitions of identity (McAlister, Scraton, and Haydon 2009; Schroeder and Risen 2016). So just as schools take time to build up trust though online activity before meeting face to face, we can also observe the need for care about selecting venues that are, in the main, on neutral terrain.

Respondents were asked to rank six factors in order of importance in choosing a venue. The three most important factors were 'travel time to the location' (mean ranking 4.57) followed by 'type of activity/curricular focus' (mean 4.25) and 'travel cost' (mean ranking 4.02), with other factors such as activity cost, facilities for SEN pupils and a venue across the border less important.

\subsection{Cost}

Costs relate to both the hiring of transport for the classes involved (typically 25-30 children per school) and costs associated with the venue. Schools were given a grant from DB towards the cost of their pupil meeting. In NI this was frozen at $£ 350$ (or $£ 700$ if more than one class in a particular school was involved) since 2006 while in Ireland the payment was based on distance of venue and averaged at $€ 600$. In response to a question about whether the grant covered all of the costs, only $34 \%$ of teachers said it did, while $66 \%$ had to find funds from elsewhere to cover the cost of the meeting. Of the latter, similar proportions were from NI $(65 \%)$ and across the border in Ireland $(66 \%)$. Teachers were asked where the additional money was raised, and $80 \%$ of responses indicated that it was from the children's families and/ or school sources. Of teachers who had to find additional funding only $20 \%$ reported that it came entirely from the school with no requests made for children to contribute. Given that two-thirds of schools needed to find additional funding for face-to-face meetings, these findings suggest significant support and commitment from schools, teachers and parents for the model of interacting face-to-face as well as online with others who are 'different', in that they live on the other side of the border.

\subsection{Levels of satisfaction}

Seventy-three per cent of teachers who had participated in a face-to-face meeting said they had been entirely happy with the experience, most regarding it as 'the highlight of the year'. Teachers, particularly those whose schools were in rural settings, noted that simply meeting other groups and going outside the everyday context was important, while one teacher explicitly noted the opportunity afforded by the face-to-face meeting to interact with pupils from a different background:

[...] our children are being brought up where they do not or tend to not meet those from another community, never let alone from another country! For them it is massive being able to meet those children physically, that there is not just an online link, ... when I see what my children get out of that experience, I see the discussion.., where children talked openly about their perceptions. that they had built up in their head over the 
years, from their own community, and to see through those times, maybe challenge those assumptions, that is massive stuff. (NI primary school)

One questionnaire item asked teachers if anything about the face-to-face meeting had been disappointing. Thirty-one $(21 \%)$ of teachers noted some dissatisfaction and commented on issues such as lengthy travel time resulting in a shortage of time for the children to be able to really bond well together, the difference in age between the two classes, the venue or the fact that the meeting was held so late in the year there was no real follow-up. However, the vast majority $(79 \%)$ of respondents did not report any disappointing aspects and given the relatively short time that the children typically spent together on these occasions, normally no more than 4-5 hours, we think that this high percentage of satisfaction should be noted. Also notable is the absence of any reported friction between the pupils in face-to-face meetings, the only negative comments made in respect of pupil interaction reflected poor choice of venue (did not offer opportunities for mixing at lunch) and in one case, the age difference between the two groups was perceived to be too large for comfortable face-to-face interaction.

\subsection{Impact of face-to-face link with online interaction}

In relation to the perceived impact of the face-to-face meeting, respondents were asked to indicate all of the suggested effects they had observed as a result of face-to-face meetings. Seventy-four per cent of respondents had noticed increased confidence and self-esteem among pupils'. This meant, according to one teacher that:

Video-conferencing sessions were more successful after the meeting as the children were able to relax more knowing their partner class. They were keener to chat during the sessions. (Questionnaire response)

A further $66 \%$ indicated 'increased communication with partner pupils online'; one teacher elucidated the reply by adding 'the project took on a more active and focused dimension once the children met each other' (questionnaire response). Others commented on the readiness of pupils to communicate more outside of normal school hours and the 'increased volume of online messages'. Sixty per cent of the sample asserted that the face-to-face meeting had led to 'increased motivation to participate in school'. One typical comment in this category was 'students involved in the DB project had full attendance on school days that they were working on Dissolving Boundaries' (questionnaire response); another noted that 'some pupils who were not very motivated with their school work, really enjoyed the DB programme and were motivated when participating in it' (questionnaire response). It seems therefore that there was a synergy between the face-to-face and online elements of the blended approach adopted in DB, manifest in both increased online engagement in school and voluntary online communication beyond the school setting.

When asked about whether the same benefits could be achieved with pupils simply interacting online, without a face-to-face meeting, only $14 \%$ of teachers were in agreement while $86 \%$ disagreed. One teacher added an interesting and unexpected comment. 'The face-to-face gives great motivation for staff as well as pupils to bring their project together and to develop relationships that could remain stagnant if it remained an online relationship' (questionnaire response). 
In other words, the face-to-face meeting, planned and managed by the teachers, deepens teacher engagement in the programme, quite apart from the benefits for the pupils.

A number of comments from teachers focused on the role of online contact prior to the face-to-face meeting and in particular the role of video-conferencing. Preparation for the face-to-face meeting involved learning the social skills needed for interacting with pupils from another school. Although they had been communicating online in forums and wikis, many teachers felt that video-conferencing was a more relevant preparation for face-to-face encounters.

When we went to (the school) there was instantaneous recognition of the students they had been video conferencing with, the whole day they chatted to each other. (Irish Special School)

Similarly, after a face-to-face meeting, teachers found that video-conferencing was more successful as pupils recognised each other and found it easier to communicate. In other words, we can see how the goals of the programme, greater intercultural awareness, affected the deployment of one of the online tools.

We conclude this section with reference to what some might see as an omission. Some readers might wonder about the absence of any mention of 'catholic' 'protestant', NI or Ireland. None of the teachers surveyed made reference to this. Given the age of the majority of pupils, most of whom would have been around 10-11 years of age, it seems that the interests of pupils and teachers lay elsewhere. As one teacher noted, it was 'lovely to see the interest in the different accents, homes, schools, lifestyle and then discover the things that are the same for them'. We can see here, evidence of the start of what might develop into ICC; at first, children look for what they have in common with others, 'the things that are the same for them'. We contend that this building of interest and curiosity about the 'other' is a sound start for children of this age.

\section{Discussion}

We draw attention in this section to three particularly important findings from the data that relate to our research question.

In relation to our main research question on the place of the face-to-face contact in this blended programme, the single most important finding was the overwhelming support from teachers for the combination of face-to-face and online learning being the best way to develop relationships.

The evidence from the data is strongly indicative that the combination of year-long online contact supplemented by face-to-face contact in the right setting has considerable benefits for both teachers and pupils. This is most likely to happen when teachers plan their face-to-face encounters in such a way that there is the maximum amount of time for social interaction between the pupils to build on the links already formed online and enough time after the event to enable the children to reflect on and consolidate their emergent relationships. The findings suggest that while teachers may be quite happy to begin the project online, ideally, where the programme lasts for a whole school year, face-to-face meetings should be organised by Spring at the latest. Evidence from the teacher interviews for this research showed that $100 \%$ of the 
cross-section who were asked about the relative roles of face-to-face and online contact, asserted that face-to-face contact was 'essential'.

Secondly, in terms of links between the face-to-face meeting and online work, we believe the finding that two-thirds of the teachers noted an increase in online communication after the face to face is important. Referring back to the work of Harwood et al. (2013) and their views about the advantages of online learning over face-to-face contact, our data allows us to say that teachers were able to get around the practical problems of organising face-to-face meetings and made good use of video-conferencing as a means of preparing pupils for the reality of a real-time 'physical' encounter. Given the relatively young age of the pupils, we were unable to say whether the positive feelings that the children experienced were transferred to the 'out-group' as a whole. We recognise that this will be an important focus for future research.

Thirdly, it has long been noted that lines between online and offline communication are not as distinct as might be assumed (Slater 2002). Thus teacher observations that pupil engagement in video-conferencing was enhanced by face-to-face contact, and vice versa, reinforce the idea that blended learning is a valuable tool for intercultural educators. Developing models of practice that can be put into operation by all teachers, not just those with specialist expertise in ICT, is an essential element of this. Our results seem to indicate that online and face-to-face interaction are complementary. This is consistent with recent research extending the contact hypothesis to include vicarious contact (e.g. Mazziotta, Mummendey, and Wright 2011) and imagined contact (e.g. Crisp and Turner 2009). Our exploration of the use of blended teaching methods for intercultural education further suggests that research on the contact hypothesis in such contexts should include consideration not only of the role of teachers but also of all forms of contact.

\section{Conclusion}

Dziuban et al. $(2016,187)$ remind us of the importance of the research context; this was critical in the case of the DB programme where the children involved were for the most part of similar physical appearance and age. This matters in the sense that when intercultural education is carried out in Israel, programme designers had to take account of the possibility that the very different appearances of orthodox Jewish children, secular Jews and Arab-Israelis could create barriers unless initial contact was done first through online work, then through audio and only when trust was being established, through face-to-face contact. Interestingly, relatively little use was made of video-conferencing in the work that has linked children from these three different sectors in Israel (Hoter, Shonfeld, and Ganayim 2009). On the island of Ireland, in spite of recent inward migration from both the European Union and further afield, outward physical appearances are not such an obvious marker of identity. Furthermore, nearly all of the children in the programme would have English as their first language and it would be accent that would be the first and most striking indicator of a child's place of origin.

It should also be noted that the data for this research was collected in 2013 at a time of relative political stability on the island of Ireland; after years of political violence and cross-border mistrust, the decision to make the bulk of the contact between pupils online, was felt to be the most acceptable in terms of pupil safety and potential parental concern. We conclude from this that the cultural setting, the age of the pupils, the 
purpose of the interaction and the specific point in time in which blended learning takes place will affect the timing and use of different technologies and face-to-face contact.

\section{Funding}

This work was supported by the Department of Education, Northern Ireland and Department of Education and Skills, Ireland.

\section{Notes}

1. Controlled schools in NI are attended almost exclusively by pupils from a Protestant community background, maintained schools are attended almost exclusively by pupils from a Catholic community background, integrated schools are attended by pupils of both community backgrounds and special schools cater for pupils from both community backgrounds who have special educational needs (SEN).

2. Findings are illustrated by quotations from both the anonymous questionnaire survey (identified as 'questionnaire response') and the interview responses (identified by school type and NI/Ireland).

\section{Notes on contributors}

Roger Austin is Emeritus Professor in the School of Education at Ulster University in NI and former co-Director of the DB programme from 1999 to 2015 . He is the author of some 70 publications on Vichy France 1940-1944, the teaching of history in NI and the use of ICT for teaching and learning. He has been involved in developing the use of ICT in teacher education and in using technologies to link schools together since 1986. A recent work, co-authored with Bill Hunter in 2013, was a global analysis of the role of ICT in bridge-building, entitled Online Learning and Community Cohesion; the Role of Schools.

Ms Angela Rickard is a Lecturer in the Department of Education in Maynooth University. Angela Rickard works mainly on the Initial Teacher Education programmes (Professional Master of Education (PME) and Bachelor of Science Education (BScEd)) in addition to supervision of Masters-level research. Angela has undertaken research involving partners nationally and internationally on themes such as Educational Technology, Development Education and Teacher Professional Development. She is currently doing doctoral-level study in the University of Bristol, using Narrative Inquiry to explore the educational experiences of Lesbian, Gay, Bisexual and Transgender (LGBT) people in Ireland.

Jacqueline Reilly is currently Head of the Research Graduate School in the Faculty of Social Sciences and Senior Lecturer in the School of Education at Ulster University. She was awarded BSSc Hons (First Class) in Psychology from Queens University Belfast in 1993 and $\mathrm{Ph} . \mathrm{D}$. in Psychology also from Queens in 1997. Appointed Lecturer in Psychology at Queens in 1998, she then moved to a position as Research Fellow in the UNESCO Centre, University of Ulster in 2002, moving to the School of Education in 2007. Research interests lie broadly within the area of education for social justice and encompass education for local and global citizenship, human rights education and training, and peace education, particularly with a focus on issues of identity and divided societies.

\section{References}

Abrams, Dominic. 2010. Processes of Prejudice: Theory, Evidence and Intervention. Equality and Human Rights Commission Research Report 56. London: EHRC. Accessed May 18, 2015. http://www.equalityhumanrights.com/sites/default/files/documents/research/56_processes_ of_prejudice.pdf.

Allport, G. W. 1954. The Nature of Prejudice. Reading, MA: Addison Wesley. 
Atkinson, M., I. Springate, F. Johnson, and K. Halsey. 2007. Inter-School Collaboration: A Literature Review. Slough: National Foundation for Educational Research.

Austin, R., and W. Hunter. 2013. Online Learning and Community Cohesion: Linking Schools. New York: Routledge.

Austin, R., J. Smyth, A. Rickard, N. Quirke-Bolt, and N. Metcalfe. 2010. "Collaborative Digital Learning in Schools: Teacher Perceptions of Purpose and Effectiveness." Technology, Pedagogy and Education 19 (3): 327-343.

Barbour, M., R. Brown, and L. H. Waters. 2011. Online and Blended Learning: A Survey of Policy and Practice from K-12 Schools Around the World. International Association for K12 Online Learning. Accessed January 11, 2015. (ED537334) http://eric.ed.gov/?id= ED537334 http://files.eric.ed.gov/fulltext/ED537334.pdf.

Barlow, F. K., M. J. Hornsey, M. Thai, N. K. Sengupta, C. G. Sibley, and M. Costantini. 2013. "The Wallpaper Effect: The Contact Hypothesis Fails for Minority Group Members Who Live in Areas with a High Proportion of Majority Group Members." PLoS One 8 (12): e82228. doi:10.1371/journal.pone.0082228.

Barshay, J. 2011. “'Blended Learning' for the Little Ones.” Education Week 31 (9): 1.

Bekerman, Z., and A. Nir. 2006. "Opportunities and Challenges of Integrated Education in Conflict-Ridden Societies: The Case of Palestinian-Jewish Schools in Israel." Childhood Education 82 (6): 327-333.

Bekerman, Z., M. Zembylas, and C. McGlynn. 2009. "Working Toward the De-essentialization of Identity Categories in Conflict and Postconflict Societies: Israel, Cyprus, and Northern Ireland." Comparative Education Review 53 (2): 213-234.

Binder, J., Hanna Zagefka, Rupert Brown, F. Funke, T. Kessler, A. Mummendey, A. Maquil, S. Demoulin, and J-P. Leyens. 2009. "Does Contact Reduce Prejudice or Does Prejudice Reduce Contact? A Longitudinal Test of the Contact Hypothesis among Majority and Minority Groups in Three European Countries." Journal of Personality and Social Psychology 96 (4): 843-856.

Bonnell, J., P. Copestake, D. Kerr, R. Passy, C. Reed, R. Salter, S. Sarwar, and S. Sheik. 2011. Teaching Approaches that Help to Build Resilience to Extremism among Young People NFER Report. Accessed January 11, 2015. https://www.gov.uk/government/uploads/system/uploads/ attachment_data/file/182675/DFE-RR119.pdf.

Borup, J., R. E. West, C. R. Graham, and R. S. Davies. 2014. "The Adolescent Community of Engagement: A Framework for Research on Adolescent Online Learning." Journal of Technology and Teacher Education 22 (1): 107-129.

Braun, V., and V. Clarke. 2006. "Using Thematic Analysis in Psychology." Qualitative Research in Psychology 3 (2): 77-101.

Çiftçi, E. Y. 2016. "A Review of Research on Intercultural Learning Through Computer-Based Digital Technologies." Educational Technology and Society 19 (2): 313-327.

Connolly, P. 2000. "What Now for the Contact Hypothesis? Towards a New Research Agenda." Race Ethnicity and Education 3 (2): 169-193.

Creswell, J. W. 2003. Research Design: Qualitative, Quantitative, and Mixed methods Approaches. 2nd ed. Thousand Oaks: Sage.

Crisp, R. J., and R. N. Turner. 2009. "Can Imagined Interactions Produce Positive Perceptions? Reducing Prejudice Through Simulated Social Contact.” American Psychologist 64 (4): 231-240.

Davies, H. 2012. "Affinities, Seeing and Feeling Like Family: Exploring Why Children Value Face-to-Face Contact." Childhood 19 (1): 8-23.

Dixon, J., K. Durrheim, and C. Tredoux. 2005. "Beyond the Optimal Contact Strategy: A Reality Check for the Contact Hypothesis." American Psychologist 60 (7): 697-711.

Dixon, J., M. Levine, S. Reicher, and K. Durrheim. 2012. "Beyond Prejudice: Are Negative Evaluations the Problem and Is Getting Us to Like One Another More the Solution?" Behavioral and Brain Sciences 35 (6): 411-425.

Dziuban, C., G. Picciano, C. Graham, and P. Moskal. 2016. Conducting Research in Online and Blended Learning Environments, 1-202. New York: Routledge.

ETI/DES. 2012. Joint Evaluation Report, Department of Education and Skills InspectorateRepublic of Ireland - Northern Ireland, Dissolving Boundaries Programme 2010/2011. 
Belfast: Education and Training Inspectorate (ETI) and Department of Education and Skills (DES).

Furcsa, L. 2009. "Outcomes of an Intercultural Email Based University Discussion Project." Language and Intercultural Communication 9 (1): 24-32.

Gallagher, T. 2008. "Diversity or Division? Experiences of Education in Northern Ireland: The Past Cannot Be Changed but the Future Can Be Developed." In Young People in Post-conflict Northern Ireland, edited by D. Schubotz and P. Devine, 67-84. Lyme Regis: Russell House.

Harwood, J., M. Hewstone, Y. Amichai-Hamburger, and N. Tausch. 2013. "Intergroup Contact. An Integration of Social Psychological and Communication Perspectives." In Communication Yearbook 36, edited by C. T. Salmon, 55-102. New York: Routledge.

Hauck, M. 2007. "Critical Success Factors in a TRIDEM Exchange." The Journal of the European Association for Computer Assisted Language Learning (ReCALL) 19 (2): 202-223.

Hoter, E., M. Shonfeld, and A. Ganayim. 2009. "Information and Communication Technology (ICT) in the Service of Multiculturalism." International Review of Research in Open and Distance Learning 10 (2).

Hughes, J. 2007. "Mediating and Moderating Effects of Inter-group Contact: Case Studies From Bilingual/Bi-national Schools in Israel." Journal of Ethnic and Migration Studies 33 (3): 419-437.

Hughes, J. 2014. "Contact and Context: Sharing Education and Building Relationships in a Divided Society." Research Papers in Education 29 (2): 193-210.

Hughes, J., and D. Blaylock. 2013. "Shared Education Initiatives in Northern Ireland: A Model for Effective Intergroup Contact in Divided Jurisdictions." Studies in Ethnicity and Nationalism 13 (3): 477-487.

Hughes, J., and C. Donnelly. 2001. Ten Years of Social Attitudes to Community Relations in Northern Ireland. Belfast: Ark. Accessed January 11, 2015. http://www.ark.ac.uk/ publications/occasional/occpaper1.pdf.

Jackman, J. R., and M. Crane. 1986. "Some of My Best Friends Are Black: Interracial Friendship and Whites' Racial Attitudes." Public Opinion Quarterly 50: 459-486.

Kassner, L. 2013. A Review of Literature: Mix It up with Blended Learning in K-12 Schools. Accessed December 10, 2015. http://eric.ed.gov/?id=ED548381.

Kilpatrick, R., and R. Leitch. 2004. "Teachers' and Pupils' Educational Experiences and School-Based Responses to the Conflict in Northern Ireland." Journal of Social Issues 60 (3): 563-586.

King, J. T. 2009. "Teaching and Learning About Controversial Issues: Lessons from Northern Ireland." Theory \& Research in Social Education 37 (2): 215-246.

Kuo, Y-C., B. R. Belland, K. E. E. Schroder, and A. E.Walker. 2014. 'K-12 Teachers' Perceptions of and Their Satisfaction with Interaction Type in Blended Learning Environments." Distance Education 35 (3): 360-381.

Ligorio, M. B., and H. van der Meijden. 2008. "Teacher Guidelines for Cross-national Virtual Communities in Primary Education." Journal of Computer Assisted Learning 24: 11-25.

Lotrecchiano, G. R., P. L. McDonald, L. Lyons, T. Long, and M. Farber. 2013. "Blended Learning: Strengths, Challenges, and Lessons Learned in an Interprofessional Training Program." Maternal and Child Health Journal 17 (9): 1725-1734.

Mazziotta, A., A. Mummendey, and S. C. Wright. 2011. "Vicarious Intergroup Contact Effects: Applying Social-Cognitive Theory to Intergroup Contact Research." Group Processes \& Intergroup Relations 14 (2): 255-274.

McAlister, S., P. Scraton, and D. Haydon. 2009. "'Insiders' and 'Outsiders': Young People, Place and Identity in Northern Ireland." Shared Space 9: 69-83.

Merryfield, M. M. 2001. "The Paradoxes of Teaching a Multicultural Education Course Online." Journal of Teacher Education 52 (4): 283-299.

Morgan, H. 2015. "Online Instruction and Virtual Schools for Middle and High School Students: Twenty-First-Century Fads or Progressive Teaching Methods for Today's Pupils? Clearing House." A Journal of Educational Strategies, Issues and Ideas 88 (2): 72-76.

O'Connor, U., B. Hartop, and A. McCully. 2002. A Review of the Schools Community Relations Programme 2002. Bangor: Department of Education.

Perry, L. B., and L. Southwell. 2011. "Developing Intercultural Understanding and Skills: Models and Approaches." Intercultural Education 22 (6): 453-466. 
Pettigrew, T. F. 1998. "Intergroup Contact Theory." Annual Review of Psychology 49: 65-85.

Pettigrew, T. F., and L. R. Tropp. 2008. "How Does Intergroup Contact Reduce Prejudice? Meta-analytic Tests of Three Mediators." European Journal of Social Psychology 38 (6): 922-934. doi:10.1002/ejsp.504.

Rickard, A., A. Grace, R. Austin, and J. Smyth. 2014. "Assessing the Impact of ICT Enriched Intercultural Work on Pupil Attitudes: Evidence From the Dissolving Boundaries Programme." International Journal of Information Communication and Technology Education 10 (3): 1-18.

Schorr, J., and D. McGriff. 2012. "Future Schools: Blending Face-to-Face and Online Learning." Education Digest: Essential Readings Condensed for Quick Review 77 (5): 30-37.

Schroeder, J., and J. Risen. 2016. "Befriending the Enemy: Outgroup Friendship Longitudinally Predicts Intergroup Attitudes in a Coexistence Program for Israelis and Palestinians.” Group Processes \& Intergroup Relations 19 (1): 72-93.

Slater, D. 2002. "Social Relationships and Identity Online and Offline." In The Handbook of New Media: Social Shaping and Consequences of ICTs, edited by L. Lievrouw and S. Livingstone, 533-546. London: Sage.

Trew, K. 1989. "Evaluating the Impact of Contact Schemes for Catholic and Protestant Children." In Growing up in Northern Ireland, edited by J. Harbinson, 131-159. Belfast: Stranmillis College, Learning Resources Unit.

Tropp, L. R., and T. F. Pettigrew. 2005. "Differential Relationships Between Intergroup Contact and Affective and Cognitive Dimensions of Prejudice." Personality and Social Psychology Bulletin 31 (8): 1145-1158.

Westermann, E. B. 2014. "A Half-Flipped Classroom or an Alternative Approach? Primary Sources and Blended Learning.” Educational Research Quarterly 38 (2): $43-57$.

Yablon, Y. B. 2007. "Contact Intervention Programs from Peace Education and the Reality of Dynamic Conflicts." Teachers College Record 109 (4): 91-1012.

Zuma, B. 2010. "The Social Psychology of (De)segregation: Rigorously Studied and Poorly Conceptualised." Psychology and Society 3 (1): 92-106.

Zuma, B. 2014. "Contact Theory and the Concept of Prejudice: Metaphysical and Moral Explorations and an Epistemological Question." Theory and Psychology 24 (1): 40-57. 